\title{
Effect of dexamethasone on hypothalamic expression of appetite-related genes in chickens under different diet and feeding conditions
}

\author{
Lei Liu, Shaohua Xu, Xiaojuan Wang, Hongchao Jiao, Jingpeng Zhao and Hai Lin ${ }^{*}$
}

\begin{abstract}
Background: Glucocorticoids (GCs) are involved in the control of appetite in birds and mammals. The effect of GCs on feed intake in birds depends on their dietary energy level. But the regulation mechanism of GCs on appetite is still unclear in chickens facing to different energy level. An experiment was conducted to investigate the effect of dexamethasone (DEX) on hypothalamic expression of appetite-related peptides in chickens fed high/low fat diet and under fasting/feeding condition.

Results: An interaction between DEX injection and dietary energy level was found on hypothalamic corticotropinreleasing hormone $(\mathrm{CRH})$ gene expression in fasted chickens $(P<0.05)$. The chickens, given a DEX injection and a low fat diet treatment, had the highest $\mathrm{CRH}$ mRNA levels than any of the fasted chickens given treatments $(P<0.05)$. Under fasting conditions, the DEX treatment significantly increased hypothalamic neuropeptide Y (NPY) and GC receptors mRNA levels $(P<0.05)$. Under re-feeding conditions, DEX treatment significantly decreased hypothalamic expression levels of NPY and agouti-related peptide (AgRP) but significantly increased the level of hypothalamic CRH expression $(P<0.05)$.

Conclusion: A regulatory network formed by NPY, AgRP and CRH is associated with the appetite-control by GCs. The result suggests that the regulation of GCs on orexigenic neuropeptides expression is dependent at least partially on dietary energy level and feeding state.
\end{abstract}

Keywords: Chickens, Glucocorticoids, Hypothalamus, Neuropeptides

\section{Background}

Hypothalami play a pivotal role in influencing feed intake in mammals and birds [1]. There are a population of neurons influencing appetite in hypothalamus, such as orexigenic neuropeptides (e.g., neuropeptide Y [NPY], agouti-related peptide [AgRP]) [1], and anorexigenic neuropeptides (e.g., proopiomelanocortin [POMC], and corticotropin-releasing hormone, $[\mathrm{CRH}])[2,3]$. The release of these neuropeptides is closely associated with the feeding state and dietary energy level. For example, the fasting for $24 \mathrm{~h}$ decreased the hypothalamic POMC

\footnotetext{
*Correspondence: hailin@sdau.edu.cn

Department of Animal Science, Shandong Agricultural University, Shandong Key Lab for Animal Biotechnology and Disease Control, Taian, Shandong 271018, China
}

and $\mathrm{CRH}$ genes expression, but increased the AgRP gene expression in chicks [4]. The mice fed with high fat diet had the lower NPY and AgRP mRNA levels [5, 6].

Peripheral signal (e.g., insulin and glucocorticoids [GCs]) is integrated in hypothalamic arcuate nucleus (ARC) of mammals or infundibular nucleus of birds $[7,8]$. GCs are involved in the appetite-control. Intracerebrovenicular (ICV) injection of GCs increases feed intake in and chicks $[8,9]$. Additionally, the effect of GCs on intake in birds depends on its dosage. Feed intake in [10]. Long-term peripheral corticosterone administration feed consumption on the comparable body weight basis [11, 12]. Bartov [13] showed that the effect of GCs on appetite was diet-type dependent, and GCs could 
stimulate feed intake of high-protein diet. Besides, fasting could not only alter the hypothalamic appetite-related genes expression [14], but also increase the blood corticosterone level [15]. GC receptors (GR) are located in hypothalamus and essential for energy balance regulation [16]. GCs stimulate NPY expression, while restraining POMC synthesis and release in birds and mammals via GR $[17,18]$. Therefore, we hypothesized that peripheral GC-induced gene expression of appetitive neuropeptides could be changed by dietary energy level as well as the feeding state.

DEX, a synthetic glucocorticoid exhibiting a high affinity for GR and a delayed plasma clearance [19], was employed in the present study to induce the hyper GCs status. And we examined the effect of GCs on hypothalamic appetitive peptides in chickens fed high/low fat diet and under fasting/feeding condition and determined the major appetitive peptides that respond to peripheral GCs.

\section{Methods \\ Animals}

Male broiler (Arbor Acres) chicks of $1 \mathrm{~d}$ were reared in an environmentally controlled room. Temperature and lighting was maintained in accordance with commercial conditions. The composition and nutrient levels of the diets of the chickens used in experiment 1 are listed in Additional file 1: Table S1. All animal experiments were reviewed and approved by the Institutional Animal Care and Use Committee of Shandong Agricultural University and performed in accordance with the "Guidelines for Experimental Animals" of the Ministry of Science and Technology (Beijing, PR China). Animal suffering was minimized as much as possible.

\section{Experimental protocol and sample collection}

At $1 \mathrm{~d}$ of age, 64 chickens of similar body weight were divided into two groups, with four replicates per group and eight chickens per replicate. Chickens were randomly subjected to one of the following two treatments: 1) feeding with high-fat diet (HFD, $15.06 \mathrm{MJ} / \mathrm{kg}, 13.5 \%$ soy oil), or 2) feeding with low-fat diet (LFD, $10.90 \mathrm{MJ} /$ $\mathrm{kg}, 0 \%$ soy oil). At $35 \mathrm{~d}$ of age, every replicate was either fasted for $24 \mathrm{~h}$ and given a dexamethasone injection (DEX, $1 \mathrm{mg} / \mathrm{kg}$ body weight/time, subcutaneous injection at 0 and $12 \mathrm{~h}$ after fasting), or fasted for $24 \mathrm{~h}$ plus a saline injection (Control, same volume as the DEX group, subcutaneous injection 0 and $12 \mathrm{~h}$ after fasting) $[20,21]$. After a 24-h period of fasting, all groups were re-fed for $3 \mathrm{~h}$ with the same diet at $40 \mathrm{~g} / \mathrm{bird}$ that they received before the fasting period. At the end of the fasting and re-feeding period, two chickens from each replicate were selected and sacrificed. A blood sample was drawn from a wing vein using a heparinised syringe. Plasma was obtained following centrifugation at $400 \mathrm{~g}$ for $10 \mathrm{~min}$ at $4{ }^{\circ} \mathrm{C}$ and then stored at $-20{ }^{\circ} \mathrm{C}$. Hypothalami were collected according to Yuan et al. [22]. After being flash-frozen in liquid nitrogen, the hypothalami were stored at $-80{ }^{\circ} \mathrm{C}$ for subsequent RNA extraction.

\section{Measurement of plasma insulin level}

Plasma glucose concentration was measured spectrophotometrically with commercial diagnostic kits (Hitachi High-Technologies Corp.; Jiancheng Bioengineering Institute, Nanjing, P.R. China). Plasma insulin was measured using radioimmunoassay with guinea pig antiporcine insulin serum (3 V Bio-engineering group Co., Weifang, P.R. China). Which have been successfully applied in poultry research [13].

\section{RNA isolation and analysis}

Total RNA extraction and qRT-PCR were performed as described previously [7]. Sequences of primers are shown in Table 1 . The PCR data were analyzed with the $2^{-\Delta \Delta C T}$ method [23]. The mRNA levels of target genes were normalised to glyceraldehyde 3-phosphate dehydrogenase (GAPDH) mRNA and $18 \mathrm{~S}$ ribosomal RNA (18SrRNA) ( $\triangle \mathrm{CT}$ ). On the basis of the Ct values, $18 \mathrm{~S}$ or GAPDH mRNA expression was stable across the treatments in this study $(P>0.1)$. The group with only LFD treatment was deemed to be 1 .

\section{Statistical analysis}

The data are presented as the mean \pm SEM. A two-way ANOVA model was used to analyze the primary effects of GCs and the dietary energy treatments as well as their interactions, using Statistical Analysis Systems statistical software package (Version 8e, SAS Institute, Cary, NC, USA). When the main effect of the treatment was significant in the analysis, the differences between means were assessed by Duncan's multiple range analysis. The mean was considered significantly different at $P<0.05$.

\section{Results}

The food intake in LFD-fed chickens was significantly higher than that of the HFD-fed ones in whole period $(P<0.05$, Fig. 1a), but the body weight gain revealed the opposite tendency from the fourth week $(P<0.05$, Fig. $1 b)$.

Dietary fat did not affect the plasma insulin concentration in fasted and re-fed chickens $(P>0.05$, Fig. 2a). However, DEX injection significantly increased the plasma insulin concentration in re-fed chickens $(P<0.05$, Fig. 2 b). In fasting chickens, DEX treatment significantly increased the plasma glucose concentration $(P<0.05)$, but diet treatment had no significant effect $(P>0.05$, Fig. $2 \mathrm{c})$. Both diet and DEX treatments had an effect on the plasma glucose concentration in re-fed chickens, and LFD and DEX treatments significantly increased the plasma glucose concentration $(P<0.05$, Fig. $2 d)$. As shown in Fig. 2 , no 
Table 1 Gene-specific primers used for the analysis of chicken gene expression

\begin{tabular}{|c|c|c|c|}
\hline Gene & GenBank accession no. & Primer sequences $\left(5^{\prime}-3^{\prime}\right)$ & Product size, bp \\
\hline \multirow[t]{2}{*}{$\overline{\text { GAPDH }}$} & NM_204305 & F: ACATGGCATCCAAGGAGTGAG & 266 \\
\hline & & R: GGGGAGACAGAAGGGAACAGA & \\
\hline \multirow[t]{2}{*}{185} & AF173612 & F: ATAACGAACGAGACTCTGGCA & 136 \\
\hline & & R: CGGACATCTAAGGGCATCACA & \\
\hline \multirow[t]{2}{*}{ NPY } & M87294 & F: GAGGCACTACATCAACCTCATCAC & 101 \\
\hline & & R: TGTITTCTGTGCTTTCCCTCAA & \\
\hline \multirow[t]{2}{*}{$\mathrm{CRH}$} & NM_001123031 & F: CTCCCTGGACCTGACTITCC & 86 \\
\hline & & R: TGTTGCTGTGGGCTTGCT & \\
\hline \multirow[t]{2}{*}{ AgRP } & NM_001031457 & F: GGAACCGCAGGCATTGTC & 163 \\
\hline & & R: GTAGCAGAAGGCGTTGAAGAA & \\
\hline \multirow[t]{2}{*}{ POMC } & NM_001031098 & F: CGCTACGGCGGCTTCA & 88 \\
\hline & & R: TCTTGTAGGCGCTTITGACGAT & \\
\hline \multirow[t]{2}{*}{ GR } & DQ227738 & F: CATGAACCTCGAAGCTCGCAAGA & 159 \\
\hline & & R: ACCTCCAGCAGTGACACCAG & \\
\hline
\end{tabular}

effect of the interaction between DEX injection and dietary fat on plasma insulin and glucose concentration was detected in fasted and re-fed chickens $(P>0.05)$.

Under fasting condition, DEX treatment significantly increased hypothalamic NPY and GR mRNA levels $(P<$ 0.05 Fig. 3a and i). Under re-feeding condition, DEX treatment significantly decreased genes expression of NPY and AgRP $(P<0.05$, Fig. $3 b$ and d). No effect of dietary energy level or the interaction between DEX injection and dietary fat level was found on the hypothalamic gene expression of NPY, AgRP, POMC or GR in fasted and re-fed chickens $(P>0.05$, Fig. 3$)$. The chickens, given a DEX injection and a LFD, had the highest CRH mRNA levels than any of the fasted chickens given treatments $(P<0.05$, Fig. $3 \mathrm{~g})$. Under re-feeding condition, a significant increase in hypothalamic $\mathrm{CRH}$ gene expression was found in HFD-fed chickens compared to the LFD-fed chickens $(P<0.05$, Fig. 3h). And DEX treatment significantly increased the CRH gene expression compared to control $(P<0.05$, Fig. 3h). An interaction effect of DEX injection and dietary fat was observed in the $\mathrm{CRH}$ gene expression in fasted chickens $(P<0.05$, Fig. $3 g)$, but not in re-fed chickens $(P>0.05$, Fig. 3h).

\section{Discussion}

In the present study, we investigated the effect of peripheral GCs on appetitive peptides of chickens in different energy situations. Our data show the following: 1) peripheral GCs increased hypothalamic NPY level in fasted chicks and CRH levels in re-fed chickens but decreased NPY and AgRP levels in re-fed chickens; 2) An
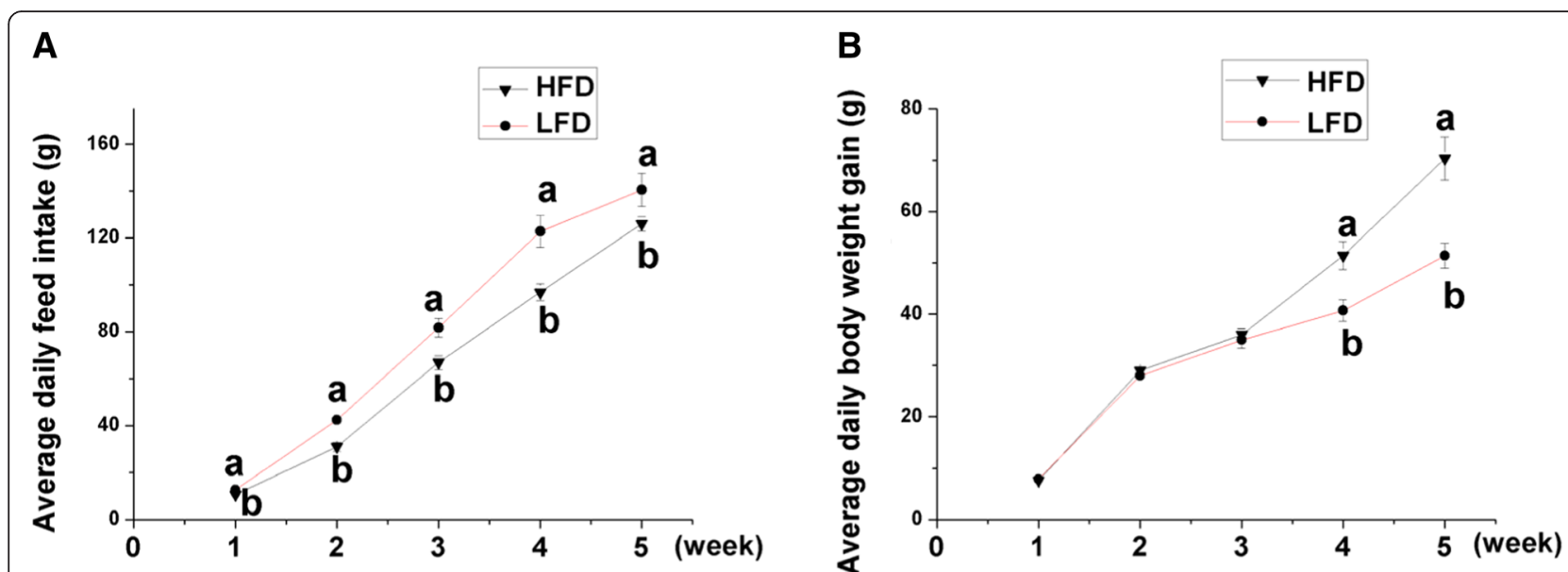

Fig. 1 Effects of Dietary fat levels on average daily feed intake (a) and body weight gain (b). Values indicate mean \pm SEM $(n=8)$. ${ }^{\text {a, b }}$ Means with different superscripts are significantly different $(P<0.05)$ 


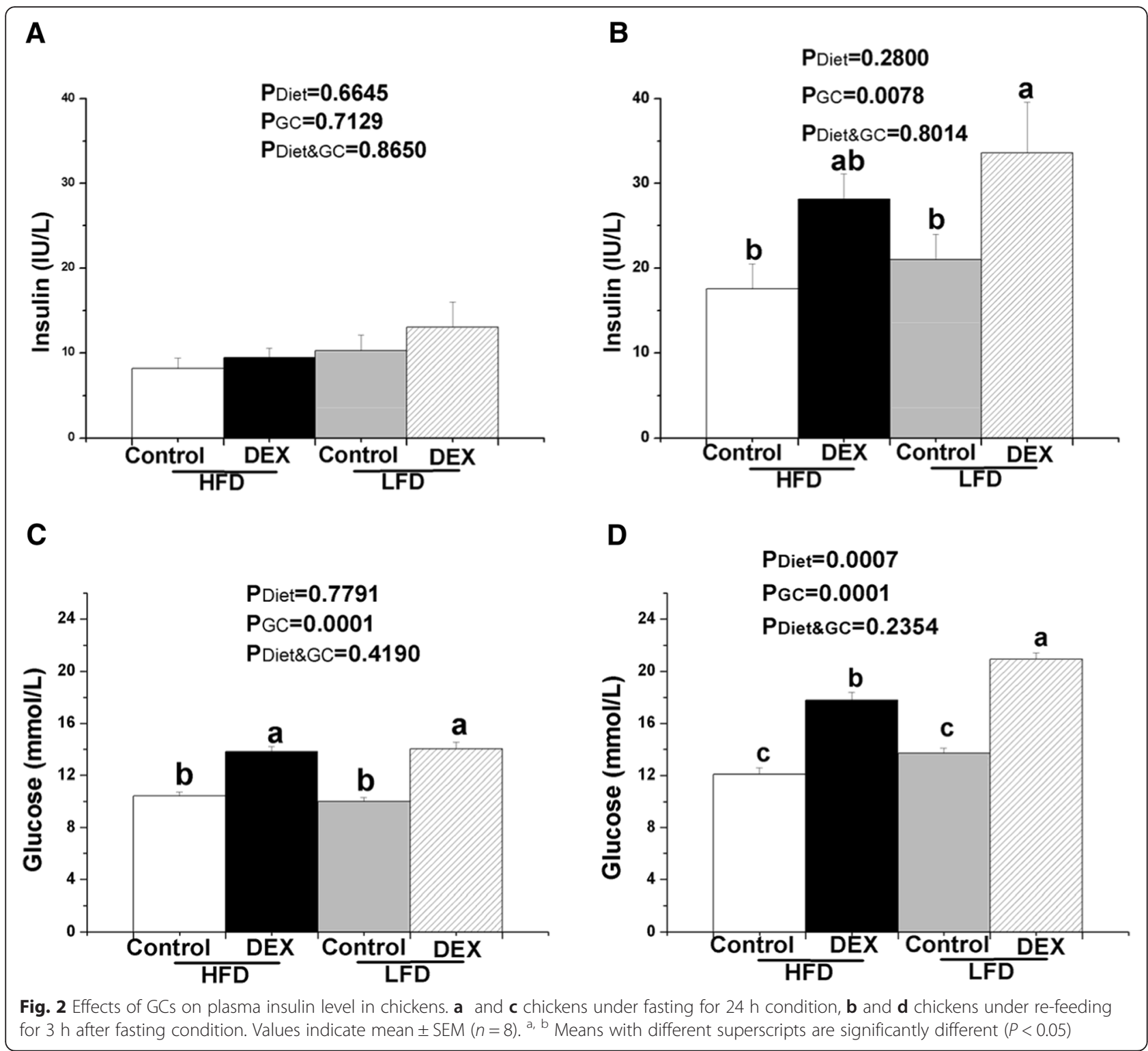

interaction effect of DEX injection and dietary fat was observed in the CRH gene expression in fasted chickens. The chickens, given a DEX injection and a LFD, had the highest CRH mRNA levels than any of the fasted chickens given treatments. The results suggest that a regulatory network formed by NPY, AgRP and CRH is associated with the appetite-control of GCs.

Diet rich in energy and fat alters the glucose/insulin response to GCs

GCs have an extensive effect in maintaining energy homeostasis. In line with previous findings [24], DEX significantly increased plasma glucose level regardless of feeding state. The result indicated that DEX treatment resulted in hyperglycaemia in both LFD and HFD chickens. The increased insulin level at re-fed state by DEX suggests the insulin resistance in DEX-chickens, in accordance with a previous publication [24]. At re-fed state, however, LFD-chicken had higher glucose and insulin levels compared with HFDchickens, suggesting that the chickens fed with LFD are more prone to develop insulin resistance by DEX challenge, compared to the chickens fed with HFD. In line with this result, our previous study showed that chickens fed with LFD could have a more severe glucose response to longterm (7 days) corticosterone exposure [25]. Collectively, the result suggests that dietary energy level could alter the glucose response to GCs challenge.

Diet rich in energy and fat alters the gene expression of orexigenic peptides

In consistent with the findings in mammals [26], body weight increased and food intake decreased significantly 

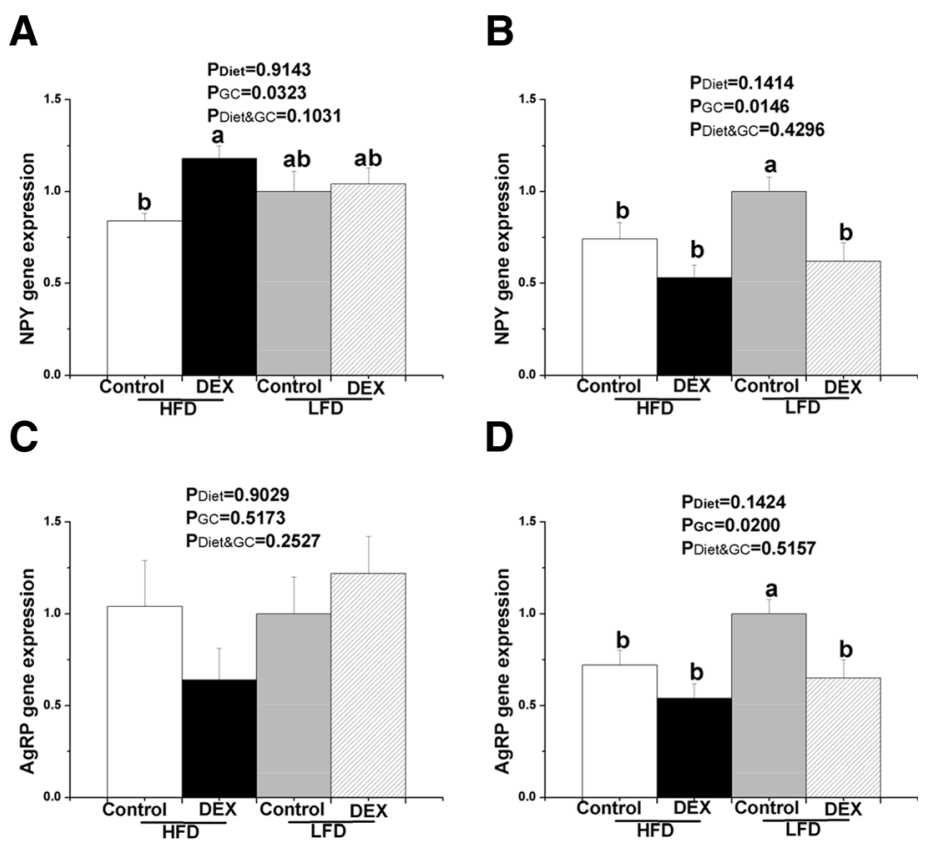

E

$\mathbf{F}$
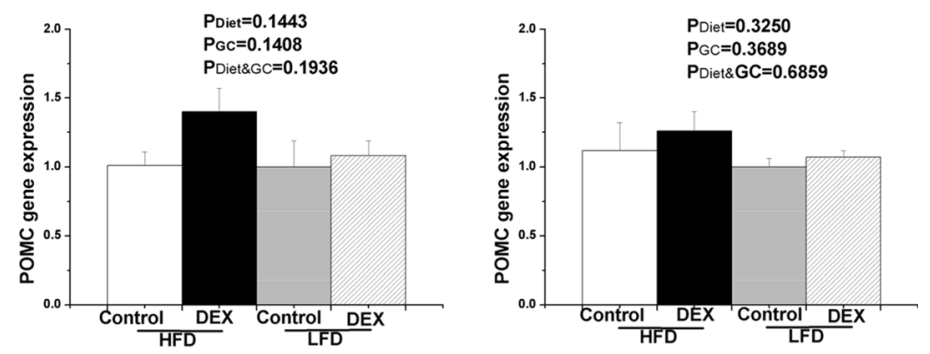

G

H
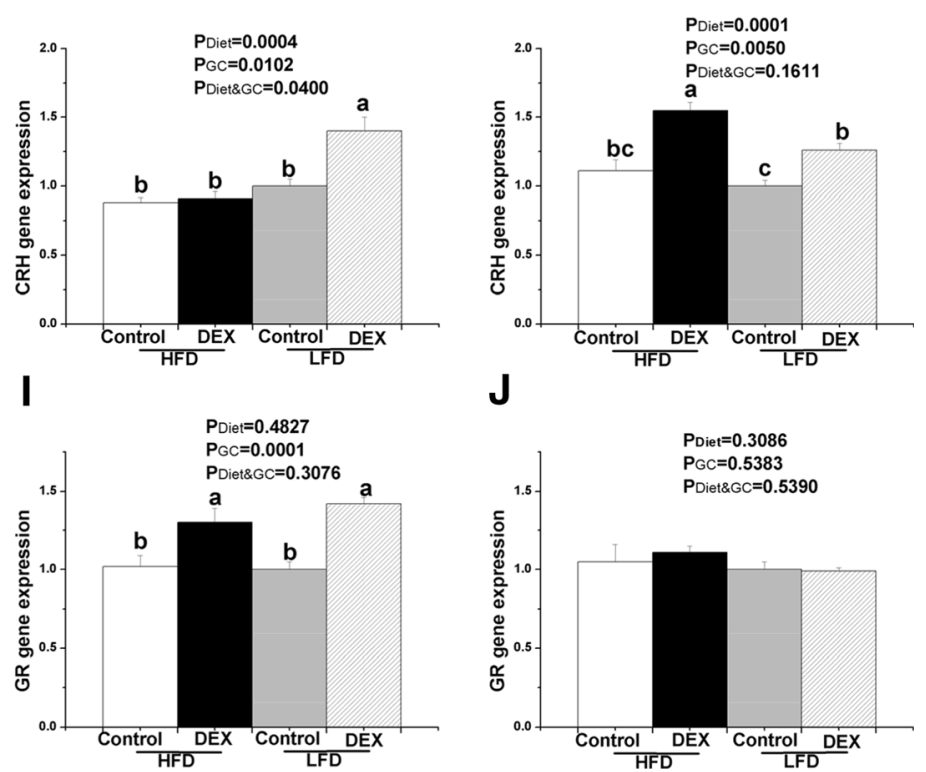

Fig. 3 Effect of GCs on hypothalamic appetitive genes expression in chickens. a, c, e, $\mathbf{g}$ and $\mathbf{i}$ chickens under fasting for $24 \mathrm{~h}$ condition, $\mathbf{b}$, d, $\mathbf{f}, \mathbf{h}$ and $\mathbf{j}$ chickens under re-feeding for $3 \mathrm{~h}$ after fasting condition. The group with only LFD treatment was deemed to be 1 . Values indicate mean \pm SEM $(n=8)$. a, b Means with different superscripts are significantly different $(P<0.05)$ 
in HFD group compared with LFD group in this study. In crassicaudata, isocaloric diet with 10,20 , or $40 \%$ of calories from fat resulted in altered food consumption [27]. The result indicated that chickens could adjust their food intake according to dietary energy level.

$\mathrm{Xu}$ et al. [28] found that the appetite alteration by HFD is related to the hypothalamic neuropeptides. In the present study, the effect of energy state on gene expression of orexigenic peptides in hypothalamus was further investigated in chickens challenged with GCs. Chicks receiving ICV NPY treatment exhibited marked hyperphagia [29]. ICV GCs injection induced high NPY gene expression in chicks $[9,30]$. At fasting state, the increased hypothalamic NPY mRNA level by GCs treatment was only detected in HFD-chickens, suggesting that the effect of peripheral GCs injection on NPY expression is dependent on dietary energy concentration. In line with the results, our previous report in laying hens feeding with normal diet showed that GCs treatment had no effect on the NPY mRNA level [31]. Furthermore, the decreased NPY mRNA level by DEX was observed in LFD-chicken at re-fed state. The result implied that the regulation of GC on NPY expression is dependent on dietary energy level and feeding state.

AgRP is another orexigenic peptide in mammals and poultry [32, 33]. The co-expression of AgRP and NPY mRNA has also been observed in the infundibular nucleus of avian species [34]. In controversy to our previous study in laying hens [31], GCs treatment didn't affect AgRP level in fasted chickens. However, there is a distinct expression of genes related to energy homeostasis and obesity in layer and broiler chickens [22]. At refed state, both AgRP and NPY genes expression were down-regulated by GCs treatment in LFD-chickens rather than in HFD-chickens, indicating that the regulation of GCs on orexigenic gene expression dependent on dietary energy level. Our recent study proved that GCs could evoke a special appetite on energy-rich diet rather than low-energy diet [35]. The result suggests that the regulation of GCs on orexigenic neuropeptides expression is dependent at least partially on dietary energy level and feeding state. GCs increased food consumption on the same basis of body weight $[11,12]$. Hence, this result implies that peripheral GCs stimulate feed consumption by upregulating the orexigenic gene expression.

\section{Diet rich in energy and fat alters the feedback signalling of peripheral GCs}

Hypothalamic POMC is an anorexigenic neuropeptide in both chickens and mammals [36, 37]. Fasting, ICV GC injection or peripheral GC administration have no significant effect on hypothalamic POMC mRNA level in avian species [9, 14, 31]. In accordance with the previous works, the present result further proved that peripheral GCs challenge, fasting, and re-fed had no influence on POMC gene expression.

$\mathrm{CRH}$ is primarily located in the periventricular part $(\mathrm{PVH})$ of the hypothalamus [38]. ICV CRH injection significantly decreased feed intake in both fed and overnight- fasted birds [39]. Peripheral GCs act on the hypothalamus and pituitary to suppress $\mathrm{CRH}$ and adrenocorticotropic hormone production in a negative feedback cycle [40]. In this study, peripheral DEX injection increased CRH mRNA level, indicating that peripheral GCs paly a feedback effect on hypothalamic CRH gene expression. As this feedback effect was not observed in HFD-chicken at fasting state, we speculated that highenergy diet can attenuate the feedback effect of GCs on hypothalamic $\mathrm{CRH}$ gene expression. However, this speculation needs to be proved further.

\section{Conclusion}

A regulatory network formed by NPY, AgRP and CRH is associated with the appetite-control by GCs. The result suggests that the regulation of GCs on orexigenic neuropeptides expression is dependent at least partially on dietary energy level and feeding state.

\section{Additional file}

Additional file 1: Table S1. The composition and nutrient levels of the experimental diets for chickens (air dry basis). (DOC $42 \mathrm{~kb}$ )

\begin{abstract}
Abbreviations
NPY: neuropeptide Y; AgRP: agouti-related peptide;

POMC: proopiomelanocortin; CRH: corticotropin-releasing hormone; ARC: arcuate nucleus; GCs: glucocorticoids; DEX: dexamethasone; ICV: intracerebroventricular; GR: GC receptors; INSR: insulin receptors; HFD: feeding with high-fat diet; LFD: feeding with low-fat diet; GAPDH: glyceraldehyde 3-phosphate dehydrogenase; 18SrRNA: $18 \mathrm{~S}$ ribosomal RNA.
\end{abstract}

\section{Competing interests}

The authors declare that they have no competing interests.

\section{Authors' contributions}

HL designed research; LL and SX conducted research; XW analyzed data; HJ provided essential reagents; LL wrote the paper. HL had primary responsibility for final content. All authors read and approved the final manuscript.

\section{Acknowledgments}

This work was supported by grants from the National Natural Science Foundation of China $(31072045,31472114,31301993)$ and the Natural Science Foundation of Shandong Province (ZR2014CP028).

Received: 19 August 2015 Accepted: 28 March 2016 Published online: 12 April 2016

\footnotetext{
References

1. Schwartz MW, Woods SC, Porte Jr D, Seeley RJ, Baskin DG. Central nervous system control of food intake. Nature. 2000;404:661-71.

2. Richards MP. Genetic regulation of feed intake and energy balance in poultry. Poult Sci. 2003;82:907-16.

3. Boswell T. Regulation of energy balance in birds by the neuroendocrine hypothalamus. J Poult Sci. 2005;42:161-81.
} 
4. Lei L, Lixian Z. Effect of $24 \mathrm{~h}$ fasting on gene expression of AMPK, appetite regulation peptides and lipometabolism related factors in the hypothalamus of broiler chicks. Asian-Australas J Anim Sci. 2012;25:1300-8.

5. Wang $H$, Storlien $L H$, Huang XF. Effects of dietary fat types on body fatness, leptin, and ARC leptin receptor, NPY, and AgRP mRNA expression. Am J Physiol-Endoc M. 2002;282:1352-9.

6. Lin S, Thomas TC, Storlien LH, Huang XF. Development of obesity and central leptin resistance in high-fat diet induced obese mice. Int J Obesity 2000;875:1-8.

7. Xu AW, Kaelin CB, Takeda K, Akira S, Schwartz MW, Barsh GS. PI3K integrates the action of insulin and leptin on hypothalamic neurons. J Clin Invest. 2005;115:951-8.

8. Zakrzewska KE, Sainsbury A, Cusin I, Rouru J, Jeanrenaud B, RohnerJeanrenaud F. Selective dependence of intracerebroventricular neuropeptide Y-elicited effects on central glucocorticoids. Endocrinology. 1999;140:3183-7.

9. Liu L, Song $Z$, Jiao H, Lin H. Glucocorticoids increase NPY gene expression via hypothalamic AMPK signaling in broiler chicks. Endocrinology. 2014;155:2190-8.

10. Covasa M, Forbes JM. Selection of foods by broiler chickens following corticosterone administration. Br Poult Sci. 1995;36:489-501.

11. Lin H, Decuypere E, Buyse J. Oxidative stress induced by corticosterone administration in broiler chickens (Gallus gallus domesticus) 1. Chronic exposure. Comp Biochem Physiol B Biochem Mol Biol. 2004;139:737-44.

12. Lin H, Decuypere E, Buyse J. Oxidative stress induced by corticosterone administration in broiler chickens (Gallus gallus domesticus) 2. Short-term effect. Comp Biochem Physiol B Biochem Mol Biol. 2004;139:745-51.

13. Bartov I. Effects of dietary protein concentration and corticosterone injections on energy and nitrogen balances and fat deposition in broiler chicks. Br Poult Sci. 1985;26:311-24

14. Song Z, Liu L, Yue Y, Jiao H, Lin H, Sheikhahmadi A, Everaert N, Decuypere E, Buyse J. Fasting alters protein expression of AMP-activated protein kinase in the hypothalamus of broiler chicks (Gallus gallus domesticus)). Gen Comp Endocrinol. 2012;178:546-55.

15. Geris KL, Berghman LR, Kühn ER, Darras VM. The drop in plasma thyrotropin concentrations in fasted chickens is caused by an action at the level of the hypothalamus: role of corticosterone. Domest Anim Endocrinol. 1999;16:231-7.

16. Savontaus E, Conwell IM, Wardlaw SL. Effects of adrenalectomy on AGRP, POMC, NPY and CART gene expression in the basal hypothalamus of fed and fasted rats. Brain Res. 2002;958:130-8.

17. Koch KA, Wingfield JC, Buntin JD. Glucocorticoids and parental hyperphagia in ring doves (Streptopelia risoria). Horm Behav. 2002;41:9-21.

18. Drouin J, Maira M, Philips A. Novel mechanism of action for Nur77 and antagonism by glucocorticoids: a convergent mechanism for $\mathrm{CRH}$ activation and glucocorticoid repression of POMC gene transcription. J Steroid Biochem Mol Biol. 1998;65:59-63.

19. Foucaud L, Niot I, Kanda T, Besnard P. Indirect dexamethasone downregulation of the liver fatty acid-binding protein expression in rat liver. Biochim Biophys Acta. 1998:1391:204-12.

20. Wang XJ, Lin H, Song ZG, Jiao HC. Dexamethasone facilitates lipid accumulation and mild feed restriction improves fatty acids oxidation in skeletal muscle of broiler chicks (Gallus gallus domesticus). Comp Biochem Physiol C Toxicol Pharmacol. 2010;151:447-54.

21. Wang XJ, Wei DL, Song ZG, Jiao HC, Lin H. Effects of fatty acid treatments on the dexamethasone-induced intramuscular lipid accumulation in chickens. PLoS One. 2012;7:e36663.

22. Yuan L, Ni Y, Barth S, Wang Y, Grossmann R, Zhao R. Layer and broiler chicks exhibit similar hypothalamic expression of orexigenic neuropeptides but distinct expression of genes related to energy homeostasis and obesity. Brain Res. 2009;1273:18-28.

23. Livak KJ, Schmittgen TD. Analysis of relative gene expression data using real-time quantitative PCR and the 2 (-Delta Delta C(T)) method. Methods. 2001;25:402-8

24. Wang XJ, Song ZG, Jiao HC, Lin H. Dexamethasone facilitates lipid accumulation in chicken skeletal muscle. Stress. 2012;15:443-56.

25. Yuan L, Lin H, Jiang KJ, Jiao HC, Song ZG. Corticosterone administration and high-energy feed results in enhanced fat accumulation and insulin resistance in broiler chickens. Br Poult Sci. 2008;49:487-95.

26. Murtaugh MA, Herrick JS, Sweeney C, Baumgartner KB, Guiliano AR, Byers T, Slattery ML. Diet composition and risk of overweight and obesity in women living in the southwestern United States. J Am Diet Assoc. 2007;107:1311-21.
27. Ng KL, Vozzo R, Hope PJ, Chapman IM, Morley JE, Horowitz M, Wittert GA. Effect of dietary macronutrients on food intake, body weight, and tail width in the marsupial S. crassicaudata. Physiol Behav. 1999;66:131-6.

28. Xu RY, Wan YP, Tang QY, Wu J, Cai W. The effects of high fat on central appetite genes in Wistar rats: A microarray analysis. Clin Chim Acta. 2008; 397:96-100.

29. Jonaidi H, Noori Z. Neuropeptide Y-induced feeding is dependent on GABAA receptors in neonatal chicks. J Comp Physiol A Neuroethol Sens Neural Behav Physiol. 2012;198:827-32.

30. Lösel R, Wehling M. Nongenomic actions of steroid hormones. Nat Rev Mol Cell Biol. 2003:4:46-56.

31. Liu L, Song Z, Sheikhahmadi A, Jiao H, Lin H. Effect of corticosterone on gene expression of feed intake regulatory peptides in laying hens. Comp Biochem Physiol B Biochem Mol Biol. 2012;162:81-7.

32. Tachibana T, Sugahara K, Ohgushi A, Ando R, Kawakami S, Yoshimatsu T, Furuse M. Intracerebroventricular injection of agouti-related protein attenuates the anorexigenic effect of alpha-melanocytestimulating hormone in neonatal chicks. Neurosci Lett. 2001;305:131-4.

33. Rossi M, Kim MS, Morgan DG, Small CJ, Edwards CM, Sunter D, Abusnana S, Goldstone AP, Russell SH, Stanley SA, Smith DM, Yagaloff K, Ghatei MA, Bloom SR. A C-terminal fragment of Agouti-related protein increases feeding and antagonizes the effect of alpha-melanocyte stimulating hormone in vivo. Endocrinology. 1998;139:4428-31.

34. Boswell T, Li Q, Takeuchi S. Neurons expressing neuropeptide Y mRNA in the infundibular hypothalamus of Japanese quail are activated by fasting and co-express agouti-related protein mRNA. Brain Res Mol Brain Res. 2002;100:31-42.

35. Song Z, Yuan L, Jiao H, Lin H. Effect of corticosterone on hypothalamic corticotropin-releasing hormone expression in broiler chicks (gallus gallus domesticus) fed a high energy diet. Asian-Australas J Anim Sci. 2011;24: 1736-1743.

36. Beaulieu S, Gagné B, Barden N. Glucocorticoid regulation of proopiomelanocortin messenger ribonucleic acid content of rat hypothalamus. Mol Endocrinol. 1988;2:27-731.

37. Benoit SC, Air EL, Coolen LM, Strauss R, Jackman A, Clegg DJ, et al. The catabolic action of insulin in the brain is mediated by melanocortins. J Neurosci. 2002;22:9048-52

38. Jósza R, Vigh S, Mess B, Schally AV. Ontogenetic development of corticotropin-releasing factor (CRF)-containing neural elements in the brain of the chicken during incubation and after hatching. Cell Tissue Res. 1986; 244:681-5.

39. Denbow DM, Snapir N, Furuse M. Inhibition of food intake by CRF in chickens. Physiol Behav. 1999;66:645-9.

40. Evans AN, Liu Y, Macgregor R, Huang V, Aguilera G. Regulation of hypothalamic corticotropin-releasing hormone transcription by elevated glucocorticoids. Mol Endocrinol. 2013;27:1796-807.

\section{Submit your next manuscript to BioMed Central and we will help you at every step:}

- We accept pre-submission inquiries

- Our selector tool helps you to find the most relevant journal

- We provide round the clock customer support

- Convenient online submission

- Thorough peer review

- Inclusion in PubMed and all major indexing services

- Maximum visibility for your research

Submit your manuscript at www.biomedcentral.com/submit 